\title{
Pemberdayaan Masyarakat Pendamping Lansia Dalam Pembuatan Teh Herbal Untuk Meningkatkan Imunitas di Masa Pandemi Covid-19
}

\author{
Sugiyanto ${ }^{1}$, Ellyvina Setya Dini \\ ${ }^{1,2}$ STIKes Panti Waluya Malang \\ Jl. Yulius Usman No.62 Malang, Indonesia
}

Email: ${ }^{1}$ sugiyantomatoya@gmail.com, ${ }^{2}$ ellyvinaenmala@gmail.com

\begin{abstract}
Abstrak
Masa pandemi Covid 19 sekarang ini terjadi banyak korban serta belum ditemukan obatnya. Langkah-langkah yang sekarang ini yang dijalankan oleh pemerintah salah satunya adalah dengan pola hidup sehat antara lain mengkonsumsi makanan sehat dan minum suplemen yang dapat meningkatkan imunitas. Tujuan dalam pengabdian masyarakat ini meningkatkan kemampuan dalam mengenalkan bahan-bahan herbal, bagian yang digunakan, takaran, kandungan, serta khasiatnya, dan meningkatkan pengetahuan masyarakat tentang manfaat teh herbal. Metode pelaksanaan yang digunakan dalam pengabdian masyarakat meliputi 3 kegiatan antara lain: Tahap persiapan: melakukan pendekatan pada grup pendamping lansia alumnis SMP Negeri 10 Surabaya angkatan 1984, dan menyiapkan bahan serta alat yang digunakan untuk pembuatan teh herbal; Tahap pelaksanaan: memberikan edukasi kesehatan, pelatihan, dan penyebaran video pembuatan teh herbal; Tahap evaluasi dilakukan terhadap apresiasi grup pendamping lansia. Hasil dari dilakukannya pengabdian adalah berjalan dengan baik dan lancar sesuai dengan yang telah dijadwalkan oleh tim pengabdian STIKes Panti Waluya Malang, hal tersebut sesuai dengan peningkatan jumlah"Like", diskusi yang aktif dari peserta.
\end{abstract}

Kata Kunci: Teh herbal, Peningkatan kesehatan, Pandemi Covid-19

\begin{abstract}
During the Covid 19 pandemic, there are currently many victims and no cure has been found. One of the steps currently being carried out by the government is a healthy lifestyle, including consuming healthy foods and taking supplements that can increase immunity. The aim of this community service is to increase the ability to introduce herbal ingredients, parts used, dosage, ingredients, and properties, and increase public knowledge about the benefits of herbal tea. The implementation method used in community service includes 3 activities, including: Preparation stage: approaching the elderly companion group, and preparing the materials and tools used for making herbal tea; Implementation stage: providing health education, training, and distributing videos of herbal tea making; The evaluation stage is carried out towards the appreciation of the elderly companion group. The result of the dedication is running well and smoothly as scheduled by the service team of the Panti Waluya Malang STIKes, this is in accordance with the increase in the number of "likes", active discussion from participants.
\end{abstract}

Keywords: Herbal tea, Health improvement, Covid-19 Pandemic 


\section{Pendahuluan}

\section{Analisis Situasi}

Seluruh dunia sedang mengalami keresahan yang disebabkan pandemi Covid-19 yang dengan cepat menyebar keseluruh dunia dimana penyebaran penyakit ini dengan cara terutama melalui pernafasan dari orang yang terpapar virus Covid-19 dan mempunyai implikasi yang begitu luas pada semua sendi kehidupan manusia apalagi sampai saat ini Covid-19 masih belum ada obat/vaksinnya (Wakhudin Dkk, 2020). Dampak tersebut juga berlaku di Indonesia yang mempunyai luas daerah dan jumlah penduduk yang begitu besar, sehingga dapat mempersulit pemberantasan pandemic Covid-19. Langkah pemerintah yang dilakukan saat ini adalah mencegah penyebaran Covid-19 dengan pola hidup sehat (dengan pemakaian masker, makan makanan yang seimbang, istirahat yang cukup, penggunaan suplemen untuk meningkatan daya tahan tubuh, jaga jarak dalam berkomunikasi, membatasi kegiatan untuk berkumpul banyak orang) (Hadiwardoyo, 2020).

Dimasa pandemi Covid 19 ini masyarakat (lansia) dituntut untuk melakukan hidup sehat antara lain dengan melakukan:

1. Eating resolution yakni, dalam masa pandemi seperti ini perlu dijaga pola makan yang baik dengan jumlah setengah piring untuk karbohidrat, protein, mineral dan vitamin ditambah konsumsi buah satu biji setiap hari, dan membantasi gula sehari tidak lebih dari 4 sendok makan, garam satu sendok teh dan lemak atau minyak tidak lebih dari 67 gram.(Putra \& Dana, 2016).

2. Exercise resolution yakni: dalam melakukan aktifitas olah raga cukup 30-45menit lebih baik dilakukan jam 8-10 pagi, serta minum air putih 8 gelas dalam sehari.(Sampurno, Kusumandyoko, \& Islam, 2020).

3. Mind and soul resolution adalah relaksasi pikiran supaya tidak stress

Profil mitra yang digunakan untuk pengabdian masyarakat ini yaitu pendamping lansia di grup alumni SMP Negeri 10 Surabaya dimana sekarang ini group alumni ini banyak mempunyai lansia dimana pada masa pandemi ini sangat membutuhkan minuman kesehatan (teh herbal) yang salah satu fungsunya untuk meningkatkan system imun tubuh lansia.

\section{Permasalahan Mitra}

Timbulnya kematian yang disebabkan oleh terjangkitnya virus covid 19 ditandai dengan adanya gejala-gejala yang berat pada orang lanjut usia apalagi yang terdapat komplikasi penyakit misalnya diabetes, jantung dibandingkan pada orang umumnya. Data dari World Health Organization (WHO) menunjukan bahwa penderita usia diatas 80 tahun ke atas mempunyai kerentanan kematian lebih tinggi $22 \%$, hal tersebut dikarenakan adanya penurunan fungsi organ akibat proses penuaan yang menyebabkan system imun tubuh tidak dapat bekerja dengan optimal seperti layaknya orang dewasa. Hal ini yang mengakibatkan tingkat keparahan apabila orang lanjut usia (lansia) mendapatkan serangan penyakit baik bakteri maupun virus (terutama virus corona atau Covid 19) dan dapat beresiko komplikasi bila lansia tersebut mempunyai penyakit komorbid (Rifa'i, Irwansyah, Sholihah, \& Yuliawati, 2020). Berdasarkan uraian tentang pentingnya usaha dalam meningkatkan imunitas pada orang lansia melalui pendamping lansia, maka melalui program pengabdian kepada masyarakat saat ini adalah dengan meningkatkan kemampuan dalam mengenalkan bahanbahan herbal, bagian yang digunakan, takaran, kandungan, serta khasiatnya, dan meningkatkan pengetahuan masyarakat tentang manfaat teh herbal. 


\section{Permasalahan Prioritas}

Cara melindungi masyarakat terutama lansia dari penularan virus corona antara lain meningkatkan penggunaan suplemen kesehatan yang dapat meningkatkan imunitas tubuh lansia. Salah satunya penggunaan sediaan teh herbal dimana teh herbal ini mengandung bahan-bahan alam yang dapat meningkatkan sistem imunitas, maka masyarakat pendamping lansia diberikan pengetahuan cara pembuatan teh herbal yang dapat berfungsi sebagai suplemen kesehatan, serta pengetahuan cara penyeduan teh herbal supaya memberikan efek bagi kesehatan

\section{Metode}

Tahap Persiapan, Melakukan pendekatan pada grup pendamping lansia dan menyiapkan bahan serta alat yang digunakan untuk pembuatan teh herbal

Tahap pelaksanaan, Memberikan edukasi kesehatan, pelatihan, dan penyebaran video pembuatan teh herbal ke grup pendamping lansia

Tahap evaluasi, dilakukan terhadap apresiasi grup pendamping lansia dengan menghitung penambahan jumlah "Like", diskusi yang aktif dari peserta pendamping lansia.

\section{Hasil dan Pembahasan}

Hasil kegiatan pengabdian kepada masyarakat dengan topik pemberdayaan masyarakat pendamping lansia dalam pembuatan teh herbal untuk meningkatkan imunitas dimasa pandemi Covid-19 dapat berjalan dengan baik dan lancar sesuai dengan yang telah dijadwalkan oleh tim Pengabdian Masyarakat STIKes Panti Waluya Malang. Keberhasilan ini terjadi atas kerjasama antara tim pengabdian masyarakat STIKes Panti Waluya dalam pembuatan sediaan teh herbal (dalam bentuk teh celup) serta para partisipasi pendamping lansia. Peran aktif peserta pendamping lansia dalam kegiatan PkM ini dapat disimpulkan baik. Hal tersebut sesuai dengan jumlah"Like" yang bertambah dari perhitungan awal, diskusi yang aktif dari pendamping lansia.

Tabel 1. Kegiatan dan Hasil Kegiatan PkM di Kabupaten Malang

\begin{tabular}{|c|c|c|c|}
\hline Waktu & Kegiatan & Tujuan & Hasil \\
\hline 13 Maret 2020 & $\begin{array}{l}\text { Persiapan Bahan Baku } \\
\text { (Pengeringan Rosela, } \\
\text { Kelor, Pegagan, Daun Teh) }\end{array}$ & $\begin{array}{l}\text { Mendapatkan sediaan } \\
\text { simplisia yang kering }\end{array}$ & $\begin{array}{l}\text { Serbuk simplisia yang } \\
\text { sudah kering dan siap } \\
\text { digunakan }\end{array}$ \\
\hline 24 Maret 2020 & $\begin{array}{l}\text { Pembelian bahan kantung } \\
\text { teh celup }\end{array}$ & $\begin{array}{l}\text { Sebagai tempat simplisia } \\
\text { (Rosela, Kelor, Pegagan, } \\
\text { The) }\end{array}$ & $\begin{array}{l}\text { Didapatkan hasil teh } \\
\text { celup herbal }\end{array}$ \\
\hline 25 Maret 2020 & $\begin{array}{l}\text { 1.Pembuatan sediaan teh } \\
\text { herbal (dalam bentuk teh } \\
\text { celup) } \\
\text { 2.Pengambilan video pada } \\
\text { saat pembuatan sediaan teh } \\
\text { herbal }\end{array}$ & $\begin{array}{l}\text { 1.Didapatkan sediaan teh } \\
\text { herbal (dalam bentuk teh } \\
\text { celup) } \\
\text { 2.Didapatkan video } \\
\text { pembuatan sediaan teh herbal } \\
\text { (dalam bentuk teh celup) }\end{array}$ & $\begin{array}{l}\text { 1. Sediaan teh herbal } \\
\text { (dalam bentuk teh celup) } \\
\text { 2.Video pembuatan } \\
\text { sediaan teh herbal (dalam } \\
\text { bentuk teh celup) }\end{array}$ \\
\hline 26 Maret 2020 & Edit video & $\begin{array}{l}\text { Didapatkan hasil video yang } \\
\text { baik }\end{array}$ & $\begin{array}{l}\text { Video pembuatan sediaan } \\
\text { teh herbal (dalam bentuk } \\
\text { teh celup) }\end{array}$ \\
\hline 27 Maret 2020 & $\begin{array}{l}\text { Pengumpulan video ke } \\
\text { LPPM }\end{array}$ & $\begin{array}{l}\text { Untuk mendapatkan link } \\
\text { edukasi }\end{array}$ & Link edukasi \\
\hline 30 Maret 2020 & $\begin{array}{l}\text { Share link edukasi ke grup } \\
\text { pendamping lansia }\end{array}$ & $\begin{array}{l}\text { Untuk memberikan edukasi } \\
\text { pada grup pendamping lansia } \\
\text { tentang pembuatan teh herbal }\end{array}$ & $\begin{array}{l}\text { Tanya jawab melalui grup } \\
\text { pendamping lansia }\end{array}$ \\
\hline
\end{tabular}



Evaluasi melalui pemberian tanda "Like" dan Diskusi pada grup pendamping lansia (dalam bentuk teh celup)

1.Mengetahui jumlah "Like" 1.Jumlah "Like" yang yang tertera pada media online

2.Agar pendamping lansia mendapatkan edukasi secara lengkap dan tepat

\section{bertambah}

2. Pendamping lansia mendapat edukasi yang dilanjutkan diskusi di grup pendamping lansia lengkap dan tepat, dan

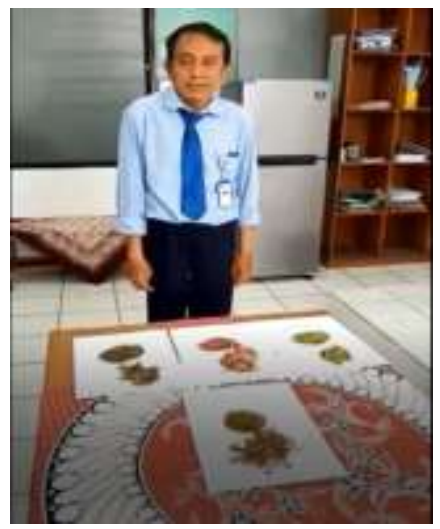

(a)

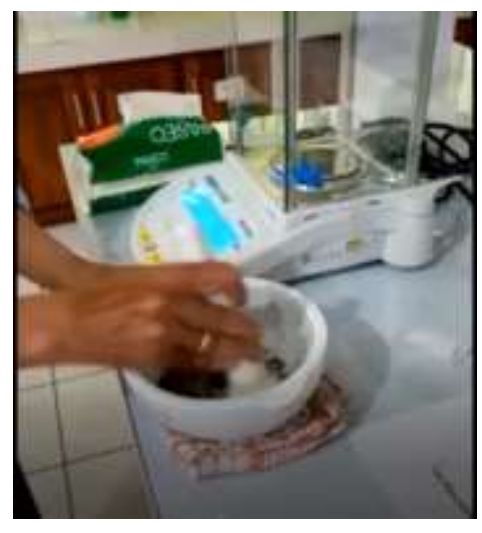

(d)

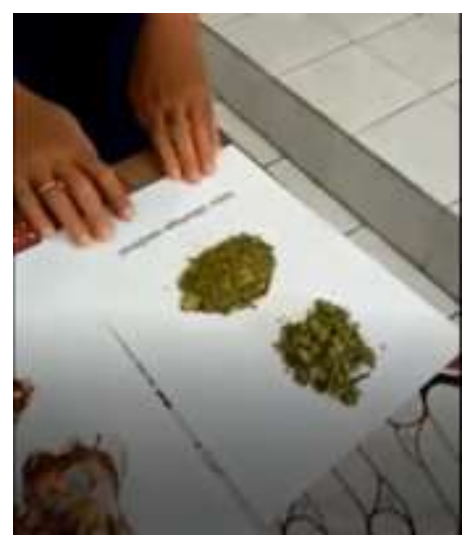

(b)

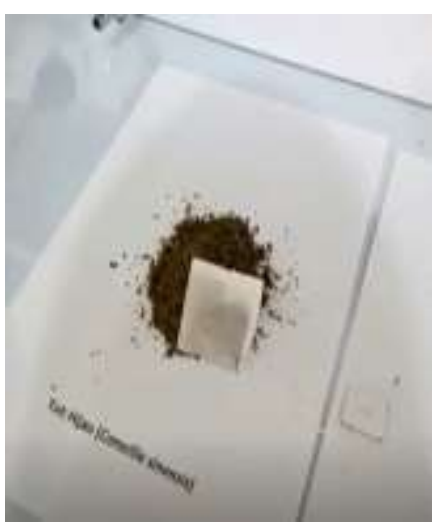

(e)

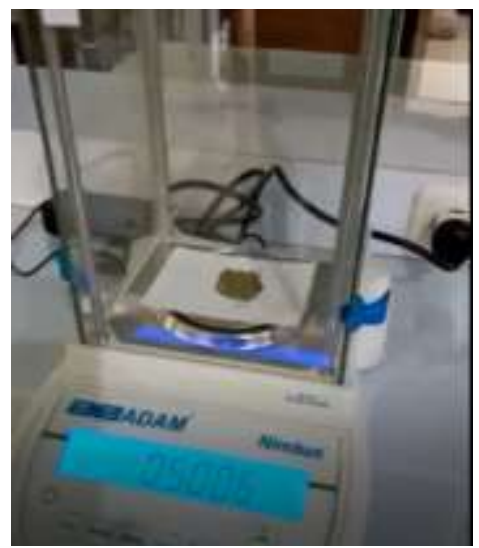

(c)

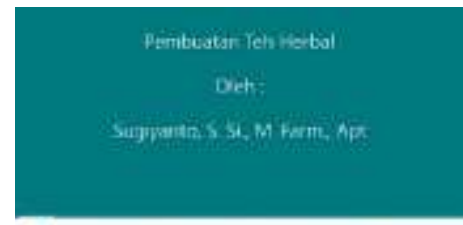

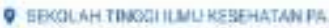
Pembsasan Teh Hetal nTehherbal ESTIKESPANTIWALUVA Whationon otomiei

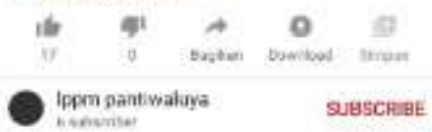

(f)

Gambar 1. Foto kegiatan (a) Bahan-bahan teh herbal (b) bahan teh herbal yang berupa simplisia dan serbuk (c) Penimbangan teh herbal (d) Pencampuran teh herbal (e) Masukan teh herbal pada kantung celup (f) link youtube PkM pembuatan teh herbal

\section{Kesimpulan}

Pelaksanaan kegiatan pengabdian masyarakat yang dilakukan oleh tim STIKes Panti Waluya Malang terhadap partisipasi pendamping lansia dapat berjalan dengan baik, lancar, dan sukses. Hal ini disebabkan adanya kerjasama yang baik antara pihak STIKes Panti Waluya dengan para partisipasi pendamping lansia pada saat pelaksanaan kegiatan tersebut yang telah dilaksanakan pada saat pembuatan sediaan serta pada saat pemberian materi edukasi dengan menggunakan video melalui media online dengan baik dan lancar serta peran partisipan 
pendamping lansia yang aktif mengikuti edukasi tersebut. Atas dasar inilah proses kegiatan pengabdian masyarakat di partisipasi pendamping lansia dapat disimpulkan dapat tercapai.

\section{Ucapan Terima Kasih}

Penulis mengucapkan terimakasih kepada (1) Yayasan Pendidikan Misericordia (2) Bapak Wibowo,S.Kep.,Ns.,M.Biomed, Selaku Ketua STIKes Panti Waluya Malang (3) Grup pendamping lansia (4) Rekan-rekan di STIKes Panti Waluya Malang

\section{Daftar Pustaka}

Hadiwardoyo, W. (2020). Kerugian Ekonomi Nasional Akibat Pandemi Covid-19. Baskara Journal of Business and Enterpreneurship, 2(2), 83-92. https://doi.org/10.24853/baskara.2.2.83-92

Pakpahan, A. K. (2020). Covid-19 dan implikasi bagi usaha mikro, kecil, dan menengah. JIHI: Jurnal Ilmu Hubungan Internasional, 20(April), 2-6. https://doi.org/https://doi.org/10.26593/jihi.v0i0.3870.59-64

Putra, I., \& Dana, I. (2016). Pengaruh Profitabilitas, Leverage, Likuiditas Dan Ukuran Perusahaan Terhadap Return Saham Perusahaan Farmasi Di Bei. E-Jurnal Manajemen Universitas Udayana, 5(11), 249101.

Rifa'i, I., Irwansyah, F. S., Sholihah, M., \& Yuliawati, A. (2020). Dampak dan Pencegahan Wabah Covid-19: Perspektif Sains dan Islam. Jurnal Pendidikan, 1(1), 1-10.

Sampurno, M. B. T., Kusumandyoko, T. C., \& Islam, M. A. (2020). Budaya Media Sosial, Edukasi Masyarakat, dan Pandemi Covid-19. SALAM: Jurnal Sosial Dan Budaya Syar-I, 7(5). https://doi.org/10.15408/sjsbs.v7i5.15210

Saragih, B. (2020). Gambaran Kebiasaan Makan Masyarakat Pada Masa Pandemi Covid-19. 19(April). Retrieved from https://www.researchgate.net/profile/Bernatal_Saragih/ publication/340830940_Gambaran_Kebiasaan_Makan_Masyarakat_Pada_Masa_Pande mi_Covid-19_Description_of_Community_Food_Habits_in_the_Covid19_Pandemic_Period/links/5ea032d3a6fdcc01dee6acc4/Gambaran-Kebiasa

Satria, A. (2020). Sosietas Jurnal Pendidikan Sosiologi Kearifan Lokal dalam Menghadapi Pandemi Covid-19 : Sebuah Kajian Literatur. Societas, 10(1), 745-753.

Tamara, B., \& Kep, S. (2019). Asuhan Keperawatan Lanjut Usia Gangguan Sistem Pencernaan "Konstipasi" Dengan Intervensi Abdominal Massage Di Era Pandemi Covid-19 Pembimbing : UNIVERSITAS KATOLIK MUSI CHARITAS.

Wakhudin Dkk. (2020). Covid-19 Dalam Ragam Tinjauan.

Wiwoho.M, S. (2020). Pandemik COVID-19: Persoalan dan Refleksi di Indonesia. 